\title{
Histopathological and Ultrastructural Changes in the Liver and Gills of the Killifish Aphanius Dispar (Cyprinodontidae) Exposed to Aflatoxin B1
}

\author{
Horiya H. Al-Azri, Taher Ba-Omar*, Abdulkadir Elshafie and Michael J. Barry
}

Department of Biology, College of Science, Sultan Qaboos University, P.O. Box: 36, PC 123, Al-Khod, Muscat, Sultanate of Oman. Email: taher@squ.edu.om.

\begin{abstract}
Aflatoxin B1 (AFB1) is a mycotoxin which can cause serious toxicity to animals and humans. The aim of this study was to investigate the effects of AFB1 in Aphanius dispar fish and measure residues in tissues after in vivo exposure. Aphanius dispar were fed diets containing 50,100, 150 and $200 \mu \mathrm{g}$ AFB1/kg for 10, 20 and 30 days. At the end of the experiment, the liver and gills were dissected out and processed for light and electron microscopy. During the experiment, no external changes or unusual behavior were observed in the fish. Histopathological and ultrastructural changes in liver appeared under all four treatments: 50, 100, 150 and $200 \mu \mathrm{g}$ AFB1/kg. Gill tissues were affected at high doses of 100,150 and $200 \mu \mathrm{g}$ AFB1/kg. Accumulation of AFB1 residues in liver and gill tissues was found to be related to a dose and duration of exposure.
\end{abstract}

Keywords: AFB1; Aphanius dispar; Liver; Gills; Fish; Ultrastructure.

التغيرات المرضية والتركيبية لكبد وخياشيم سمك الصد بعد تعرضها لسميات الافلاتوكسن AFB1

$$
\text { حورية هلال العزرية ، طاهر باعمر ، عبدالقادر الثفيع ومايكل باري }
$$

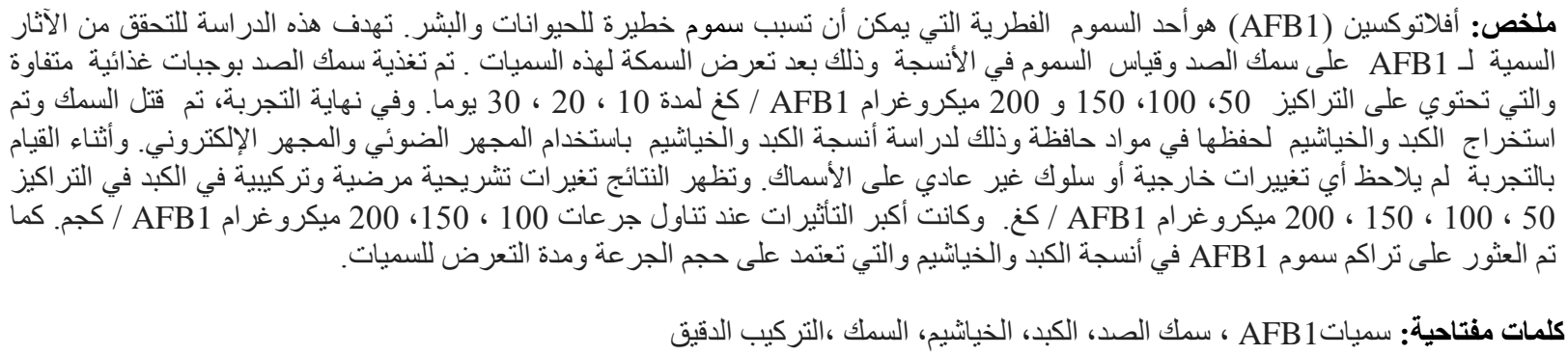

\section{Introduction}

A flatoxins are naturally occurring mycotoxins that are produced as secondary metabolites by several fungi, mainly Aspergillus flavus and Aspergillus parasiticus. Aflatoxin B1 is the most prevalent and biologically active aflatoxin and is strongly carcinogenic, mutagenic and teratogenic in humans and animals [1, 2]. Although aflatoxins have been detected in food products worldwide, they are much more prevalent in regions with hot and humid climates that favor the growth of the two Aspergillus species.

Commercial aquaculture is a relatively recent development in the Middle-East, but may eventually form an important source of economic activity in the region. The climate of northern Oman is hot and humid and provides an ideal environment for production of aflatoxins. Previous studies have detected significant levels of aflatoxins or Aspergillus species in local black tea, spices and herbal medicine [3-5].

The toxicity of aflatoxins has been measured in rainbow trout [6], sea bass [7], coho salmon [8], Nile tilapia [9] and channel catfish [10]; however, most studies have focused on its effects on growth or tumour formation. Susceptibility to the toxic effects of aflatoxins varies widely between species. The effects are influenced by species, sex, age, dose level, period of exposure to the toxin, nutritional status and effect of other chemicals [11]. 
The Killifish, Aphanius dispar (Rüppell, 1828) (Teleostei, Cyprinodontidae) is a common fish in Oman and has been used as a model organism for toxicity testing [12,13]. The first signs of toxicological damage often appear at the level of the cell, and structural changes can act as bioindicators of harm. AFB1 is bioactivated by the cytochrome P450 system form [ $\left.{ }^{3} \mathrm{H}\right]$ AFB1-DNA adduct(s) [14]. The highest concentrations of cytochrome P450 occur in the liver and this is commonly reported as a major site of aflatoxin toxicity. The gills are in close contact with both the external environment and the blood system, and are important organs for respiration, osmoregulation, acid-base balance and nitrogenous waste excretion in aquatic animals. However, little is known about the impact of aflatoxins on gill structures. The aims of this study were to investigate the histopathological and ultrastructural changes in liver and gills of Aphanius dispar and quantify AFB1 residues in these tissues.

\section{Materials and methods}

Aphanius dispar (0.6-3.9 g; 2-6 cm) were collected from a spring-fed channel and acclimatized to laboratory conditions for at least ten days before the start of the experiments. The fish were maintained in aerated glass aquaria $(50 \times 30 \times 25 \mathrm{~cm})$ filled with 17 liters of de-chlorinated tap water, with a photoperiod of 12 hours light to 12 hours dark. Every 48 hours 50-70\% of the aquarium water was changed while the $\mathrm{pH}$ and ammonia of the water were measured weekly. Fish were fed once a day with a commercial fish feed, Tetra Min ${ }^{\circledR}$ (Tetra GmbH. D49304, Germany).

A stock solution of AFB1 was prepared by dissolving $2 \mathrm{mg}$ of $99.9 \%$ pure AFB1 (Sigma, USA) in $10 \mathrm{ml}$ of $30 \%$ analytical grade ethanol. Test solutions were prepared using a dilution of the stock in $30 \%$ ethanol. Four different concentrations of AFB1 were prepared (50, 100, 150 and $200 \mu \mathrm{g}$ AFB1/kg).

One hundred fish, divided into five groups of 20 fish and placed into separate aquaria under a fume hood,

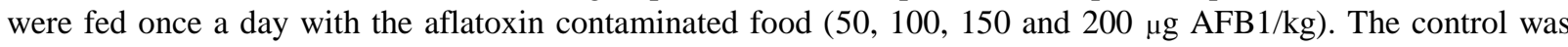
fed once a day with feed mixed with ethanol free of AFB1.

On days 10, 20 and 30 after the start of the experiment, five fish were randomly collected from each tank. The fish were anaesthetized by placing them in chilled water and their weight and length were measured. The liver and gills were then dissected out. Portions of liver and gills were immediately fixed in $10 \%$ buffered formalin and processed for light microscopy. Sections were stained with Hematoxylin and Eosin (H \& E). Small portions of the liver and gills were also fixed in $2.5 \%$ Karnovsky fixative at $4{ }^{0} \mathrm{C}$ for $4 \mathrm{~h}$ and then washed twice with sodium cacodylate buffer at a $\mathrm{pH}$ of 7.4 and finally double fixed with osmium tetroxide. To process the tissues for transmission electron microscopy, semi-thin and ultra-thin sections were cut using an ultra-microtome. The semithin sections were stained with toluidine blue and the ultra-thin sections were stained with uranyl acetate and lead citrate and were observed under a JEOL JEM-1230 transmission electron microscope operating at $80 \mathrm{kV}$.

AFB1 residues in the liver and gills were also measured on days 10, 20 and 30. Fish from each treatment were removed and anaesthetized, and the liver and gill tissue were removed and weighed. Residues were measured using a commercial test kit (VICAM ${ }^{\mathrm{TM}}$ Aflatest, USA).

\section{Results}

During the experiment, water parameters remained within acceptable limits (Temp: $27 \pm 1{ }^{0} \mathrm{C}$; Ammonia: $0.009 \pm 0.02 \mathrm{mg} / \mathrm{L} ; \mathrm{pH}: 6-8)$. There was no mortality and fish behaved normally.

\section{Light Microscopy (LM)}

Liver

The livers of control fish had polyhedral hepatocytes, with homogenous cytoplasm and large spherical centrally located nuclei (Figure 1A). The hepatocytes contained glycogen granules and few lipid droplets of various sizes. On day 10, the livers of fish treated with 50 and $100 \mu \mathrm{g}$ AFB1/kg were normal. On days 20 and 30 fish treated with $50 \mu \mathrm{g}$ AFB $1 / \mathrm{kg}$ showed hepatocellular vacuolation, where the vacuoles appear as sharply rounded spaces with distinct outlines and displace the nucleus to the periphery (Figure 1B). These vacuoles were assumed

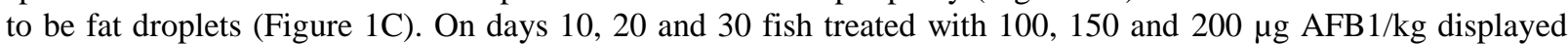
hepatocellular degeneration especially at a concentration of $200 \mu \mathrm{g}$ AFB $1 / \mathrm{kg}$, fish treated with which exhibited diffuse advanced fatty change where most hepatocytes had a signet-ring appearance with formation of fat cysts on the $30^{\text {th }}$ day of exposure (Figure 1D-F).

Gills

The gills of control fish had distinct primary and secondary lamellae (Figure 2A). The region between the secondary lamellae and the primary lamellae was lined with stratified squamous epithelium. This region contained the mucous cells and chloride cells. On day 10, the gills of fish treated with 100, 150 and $200 \mu \mathrm{g}$ AFB1/kg showed mild epithelial hyperplasia with lamellar fusion, and mild desquamation of secondary lamellae (Figure 2B). On day 20 , fish treated with 100,150 and $200 \mu \mathrm{g}$ AFB1/kg showed mucous degeneration characterized by goblet cell 
hyperplasia of the basal epithelial cells (Figure 2C). On day 30, fish treated with 100, 150 and $200 \mu \mathrm{g} \mathrm{AFB1/kg}$ showed multifocal lamellar necrosis (Figure 2D).
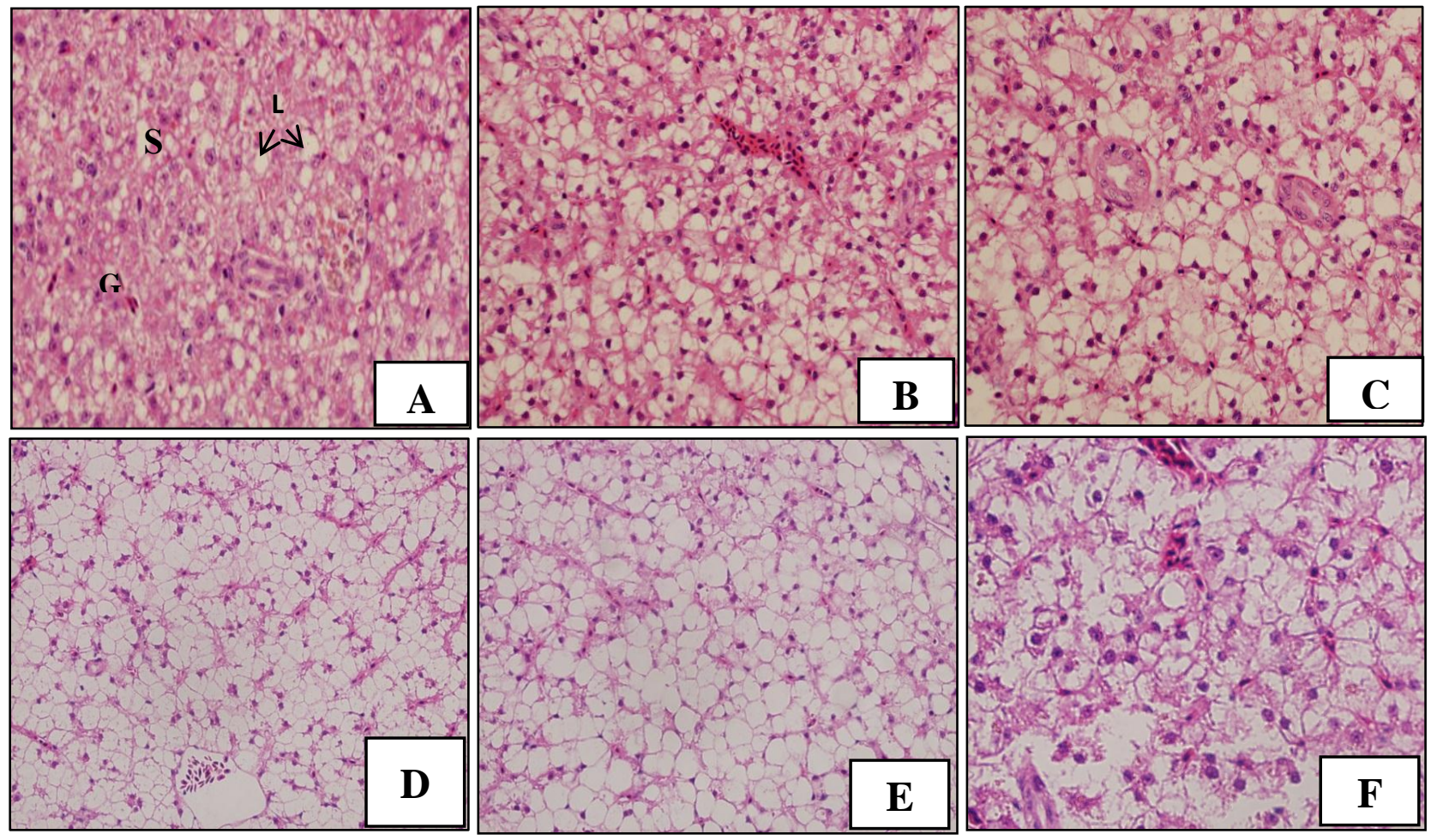

Figure 1. Light micrographs of $\mathrm{H} \& \mathrm{E}$ stain of A. dispar liver showing: A) Control liver; B) Liver of fish treated with $50 \mu \mathrm{g}$ AFB $1 / \mathrm{kg}$ for 20 days; C) Liver of fish treated with $50 \mu \mathrm{g}$ AFB 1/kg for 30 days. Sinusoid (S); lipid (L); glycogen (G); D) Liver of fish treated with $200 \mu \mathrm{g}$ AFB1/kg for 10 days ; E) Liver of fish treated with $200 \mu \mathrm{g} \mathrm{AFB} 1 / \mathrm{kg}$ for 20 days; F) Liver of fish treated with $200 \mu \mathrm{g}$ AFB1/kg for 30 days X400.
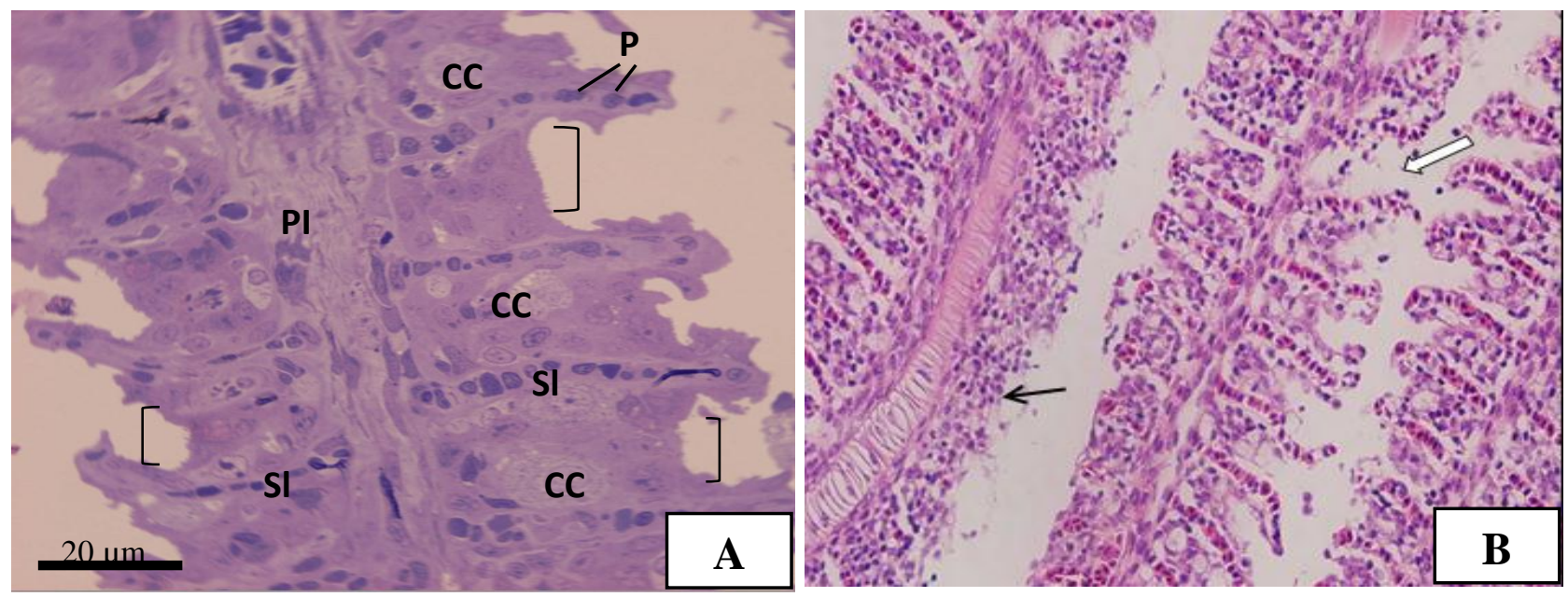

Figure 2. Light micrographs of gills showing: A) Gills of control fish; B) Gills of fish treated with $100 \mu \mathrm{g} \mathrm{AFB} 1 / \mathrm{kg}$ for 10 days. 

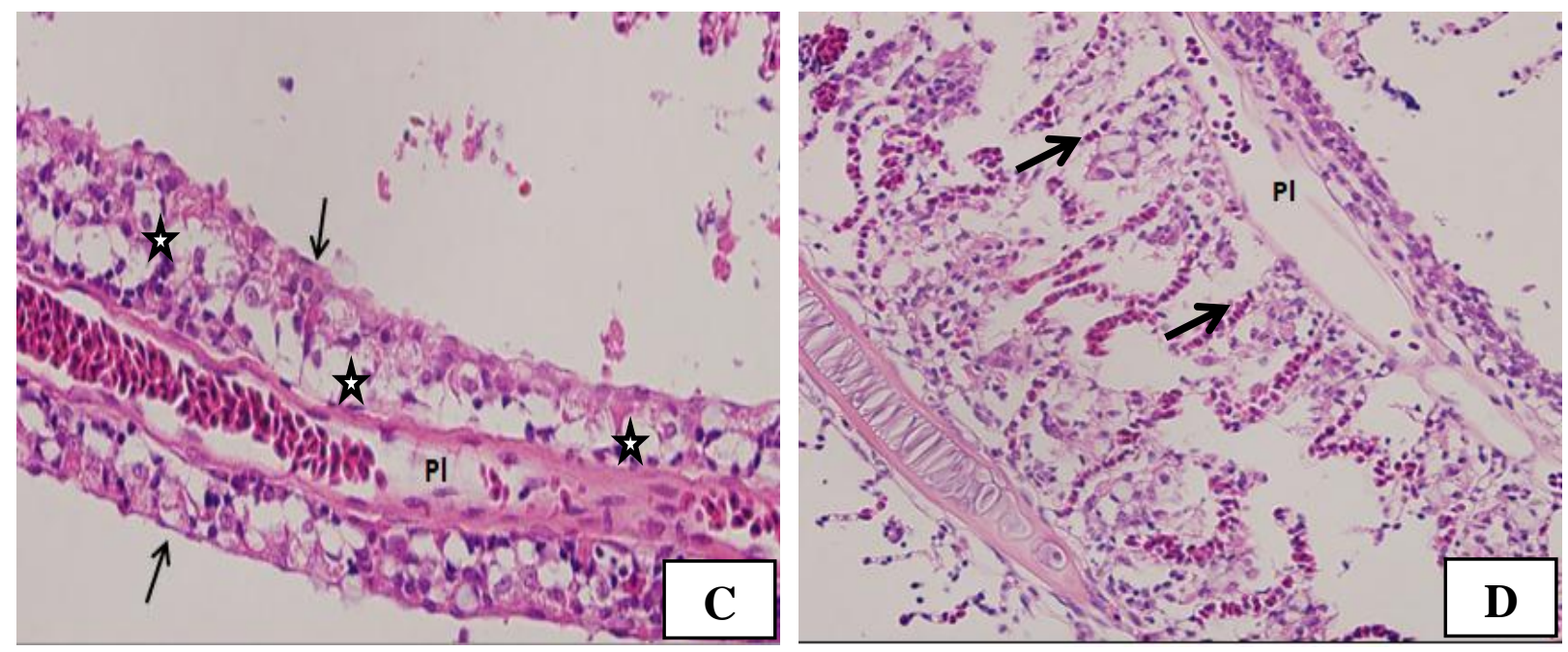

Figure 2. Light micrographs of gills showing: C) Gills of fish treated with $150 \mu \mathrm{g}$ AFB $1 / \mathrm{kg}$ for 20 days; D) Gills of fish treated with $200 \mu \mathrm{g}$ AFB1/kg for 30 days. Primary lamella (Pl); Secondary lamella (Sl) Chloride cell (CC); Pillar cell (P); Lamellar fusion (brackets); desquamation (white arrow); hyperplasia (black arrows); hypertrophy of chloride cells (stars); necrosis (thick black arrows ); A (Toluidine blue stain), B-D (H\&E stain), X400.

\section{Transmission Electron Microscopy (TEM)}

Liver

Hepatocytes of the control fish showed normal cytoplasmic organelles such as rough endoplasmic reticulum (RER) and mitochondria, and were enriched with glycogen (Figure 3). RER was arranged near the nucleus in 7-10 parallel arrays next to the plasmatic membrane. Mitochondria appeared as spherical or elongated profiles with numerous cristae and were often surrounded by RER (Figure 3).

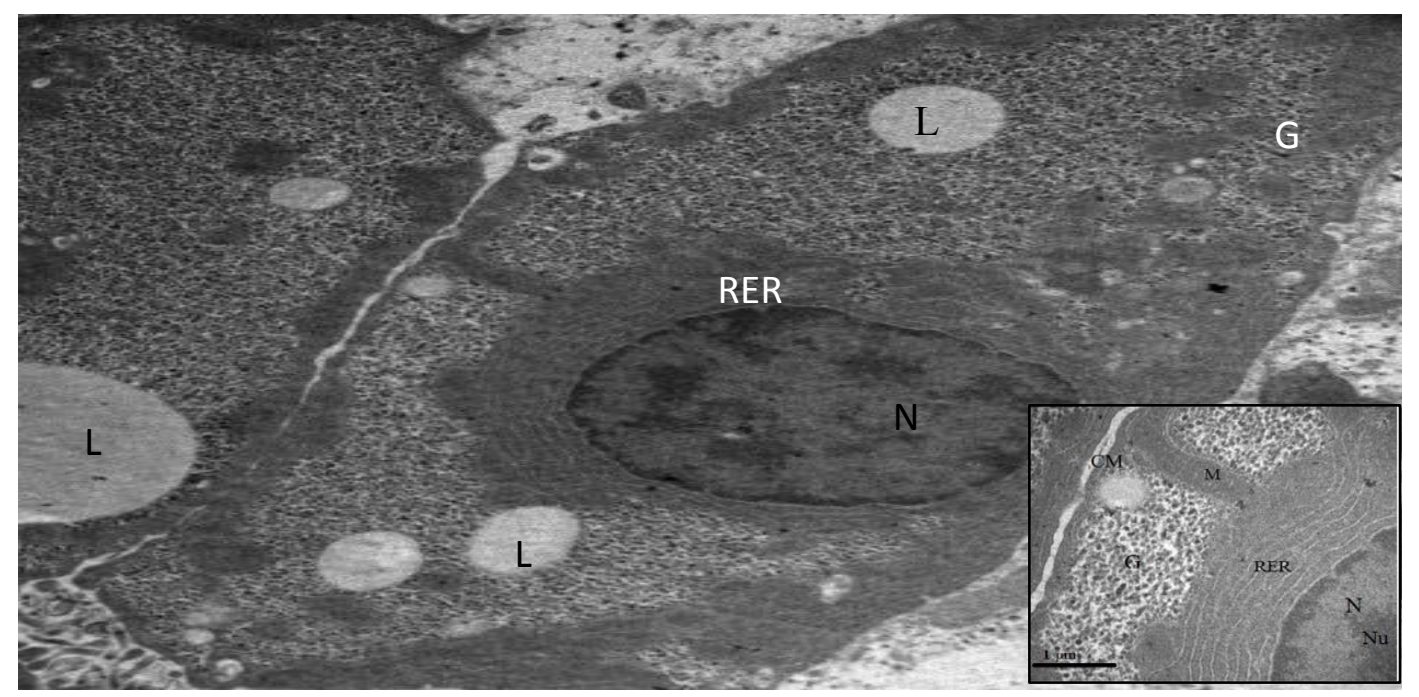

Figure 3. Electron micrographs of the control fish liver showing: cell membrane (CM); lipid droplet (L); nucleus $(\mathrm{N})$; nucleolus $(\mathrm{Nu})$; rough endoplasmic reticulum (RER); mitochondria $(\mathrm{M})$ and glycogen $(\mathrm{G})$.

On day 10, fish treated with concentrations $\geq 50 \mu \mathrm{g} \mathrm{ABF1/kg}$ showed an increase in the number of lipid droplets and lysosomes, irregular shaped nuclei, vacuolation in the cytoplasm and swelling of the mitochondria (Figures 4, 5). More damage was seen on days 20 and 30, including an increase and accumulation of lipid droplets, condensation of chromatin, an increase of vacuolation in the cytoplasm, reduced amounts of glycogen, loss of the cellular membrane, loss of mitochondrial cristae, and disarrangement and destruction of rough endoplasmic reticulum (RER) (Figure 6). 

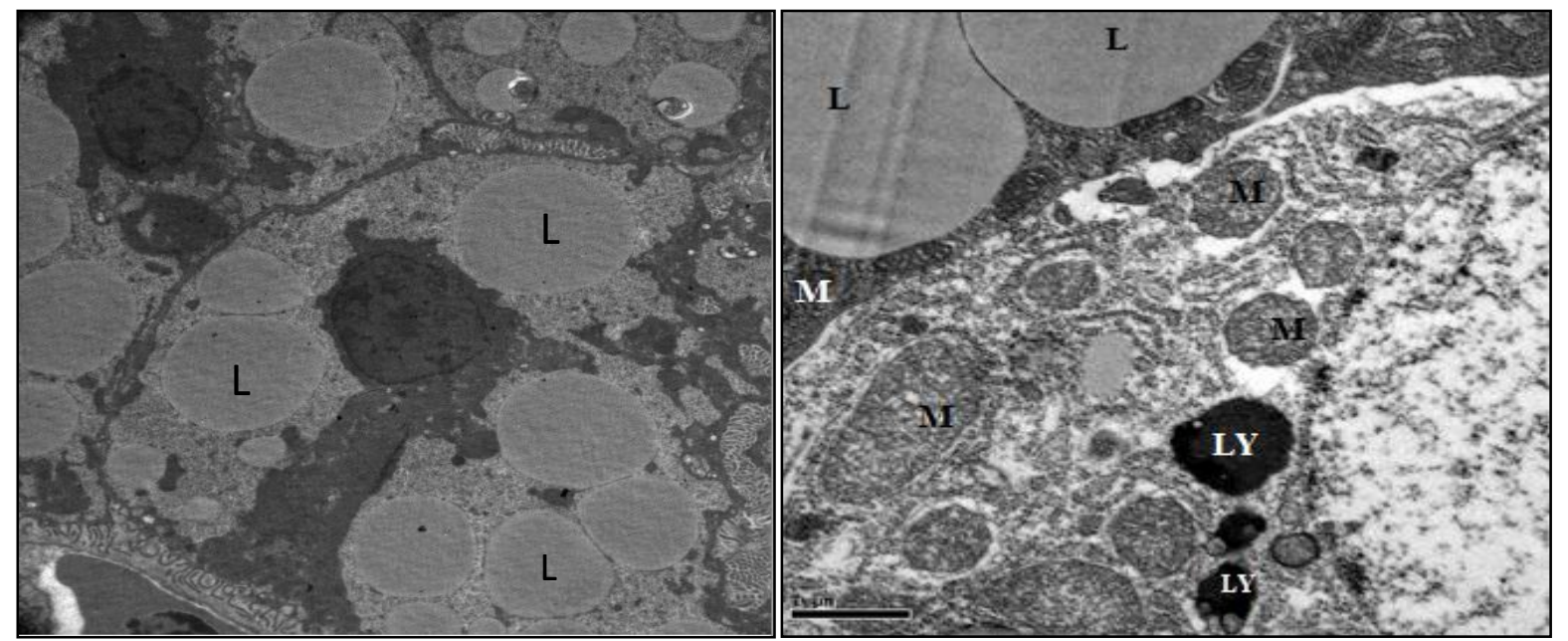

Figure 4. Electron micrographs of fish liver: A) Liver of fish treated with $50 \mu \mathrm{g}$ AFB $1 / \mathrm{kg}$ for 20 days; B) Liver of fish treated with $70 \mu \mathrm{g}$ AFB1/kg for 20 days: B) mitochondria (M); lysosome (LY); lipid droplet (L).
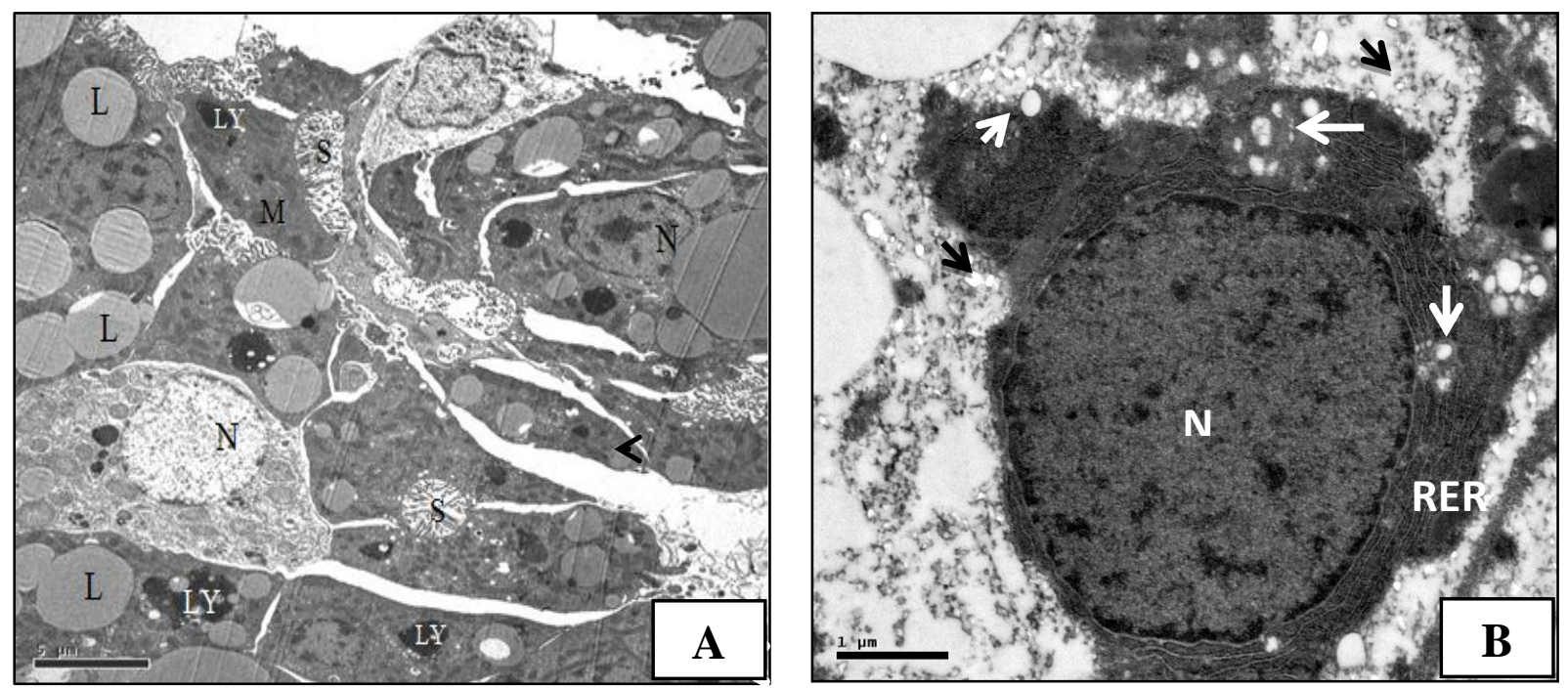

Figure 5. Electron micrographs of fish liver: A) Liver of fish treated with $70 \mu \mathrm{g}$ AFB $1 / \mathrm{kg}$ for 30 days; B) Liver of fish treated with $150 \mu \mathrm{g}$ AFB1/kg for 10 days, mitochondria (M); lysosome (LY); lipid droplet (L); cytoplasmic vacuoles (arrows) and nucleus $(\mathrm{N})$.

Gills

Four different cell types could be differentiated in the primary lamellae; basal cells, chloride cells, accessory cells, and pavement cells (PVC) (Figure 7). The chloride cells were often distributed in the interlamellar region and were characterized by abundant mitochondria (Figure 7A). Accessory cells (filament-rich cells) are flat, found between neighboring chloride cells, and had denser cytoplasm than chloride cells with few mitochondria. Secondary lamellae consisted of two epithelial cell layers separated from the pillar cells by a basement membrane. In addition, the PVC of the secondary lamellae were polygonal in shape, and displayed smooth surfaces with only long micro-ridges running parallel to the cells (Figure 7B ). After ten days, fish treated at 100, 150 and $200 \mu \mathrm{g}$ AFB $1 / \mathrm{kg}$, showed changes including irregular shaped nuclei of the chloride cells, chromatin condensation of nuclei and increased size of goblet cells (Figure 8A). By day 20, there were signs of damage to the cellular membrane and cytoplasmic vacuoles in many chloride cells (Figure 8B). On day 30, severe cellular damage, dilation of primary lamellae, degeneration (cell death) of epithelial cells in primary and secondary lamellae, hypertrophy of chloride cells, and the appearance of some chloride cells with degenerative nucleus and large cytoplasmic vacuolation were apparent (Figure 9). 

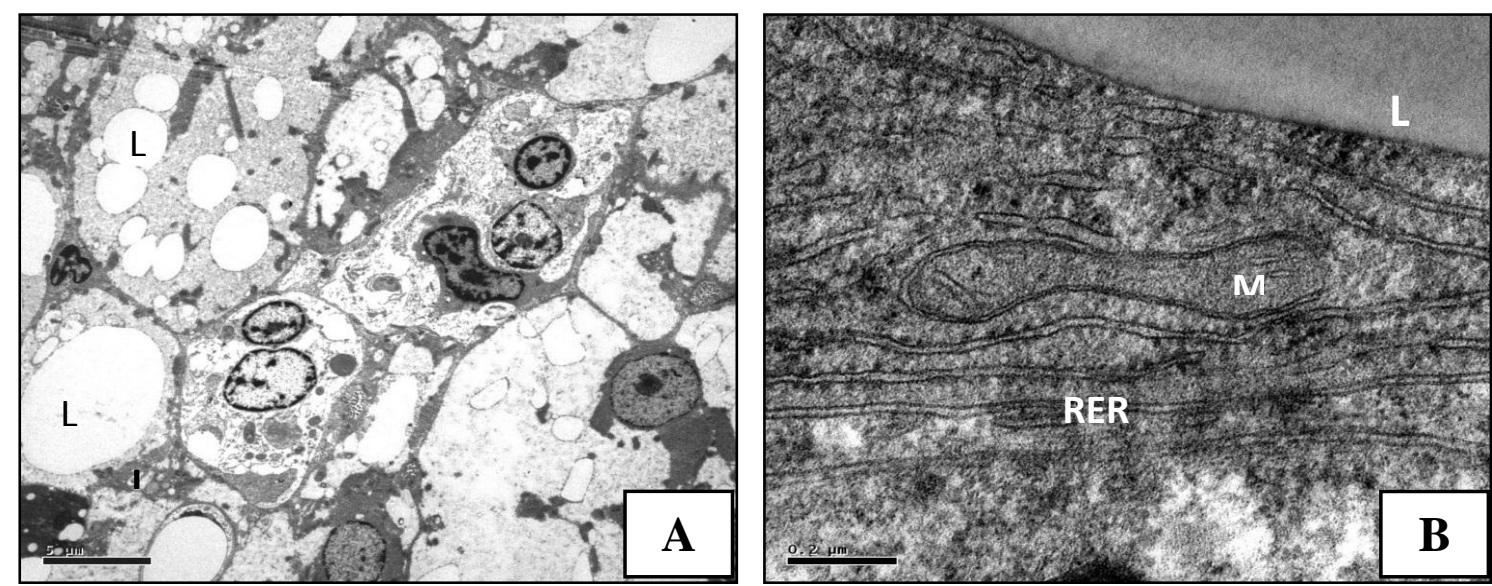

Figure 6. Electron micrographs of fish liver treated with $200 \mu \mathrm{g}$ AFB $1 / \mathrm{kg}$ for 30 days (A\&B) showing: mitochondria $(\mathrm{M})$; rough endoplasmic reticulum (RER); lipid droplet (L).

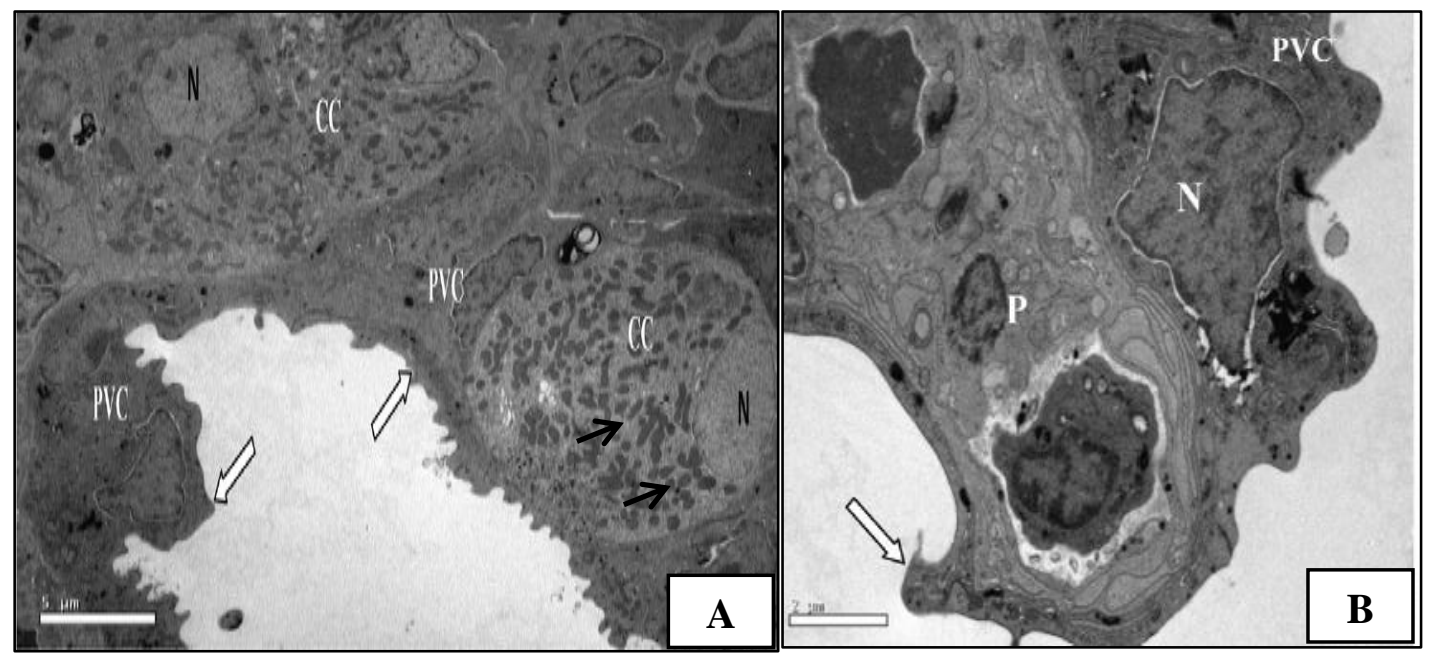

Figure 7. Electron micrographs of the gill of the control (A\&B) showing: A) Inter lamellar space; B) Secondary lamellae; chloride cell (CC); pavement cell (PVC); pillar cell (P); nucleus $(\mathrm{N})$; mitochondria (black arrows); microridges (white arrows).
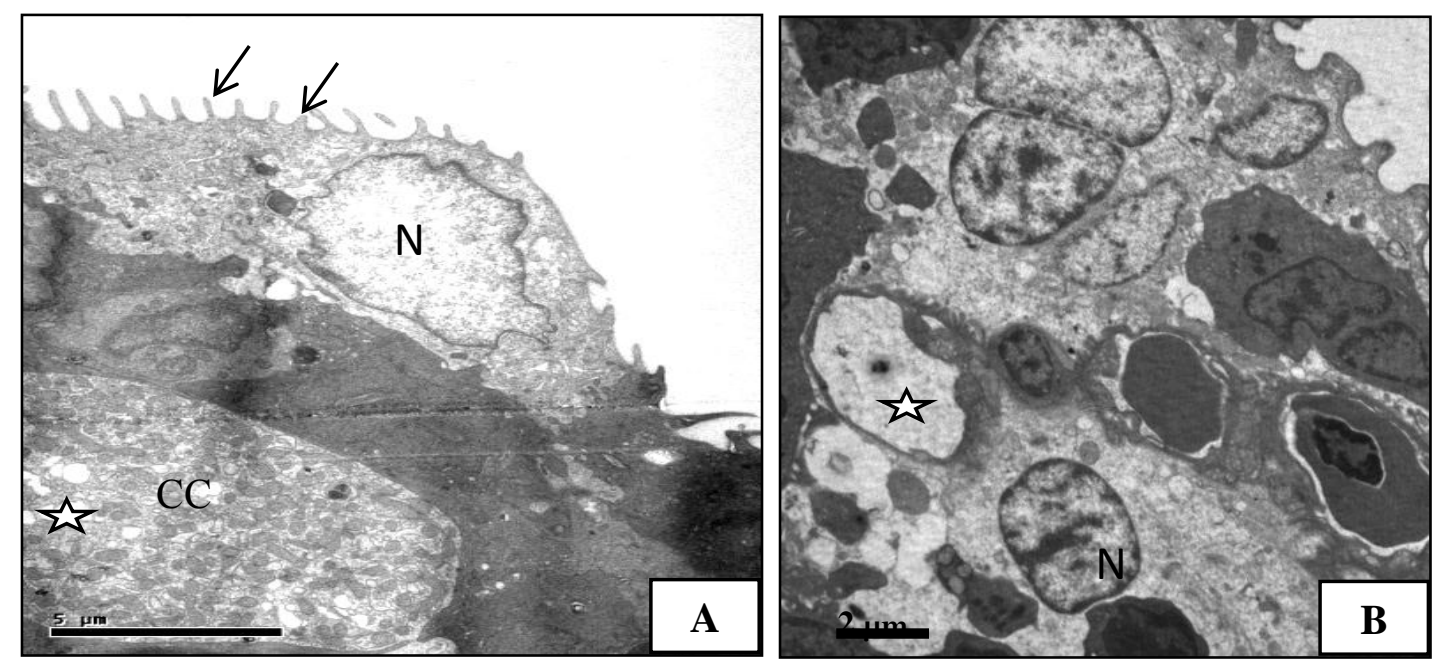

Figure 8. Electron micrographs of the gill. A) Gill of fish treated with $100 \mu \mathrm{g}$ AFB $1 / \mathrm{kg}$ for 10 days; B) Gill of fish treated with $100 \mu \mathrm{g}$ AFB 1/kg for 20 days; chloride cell (CC); nucleus (N); microridges (arrows); vacuoles (stars). 

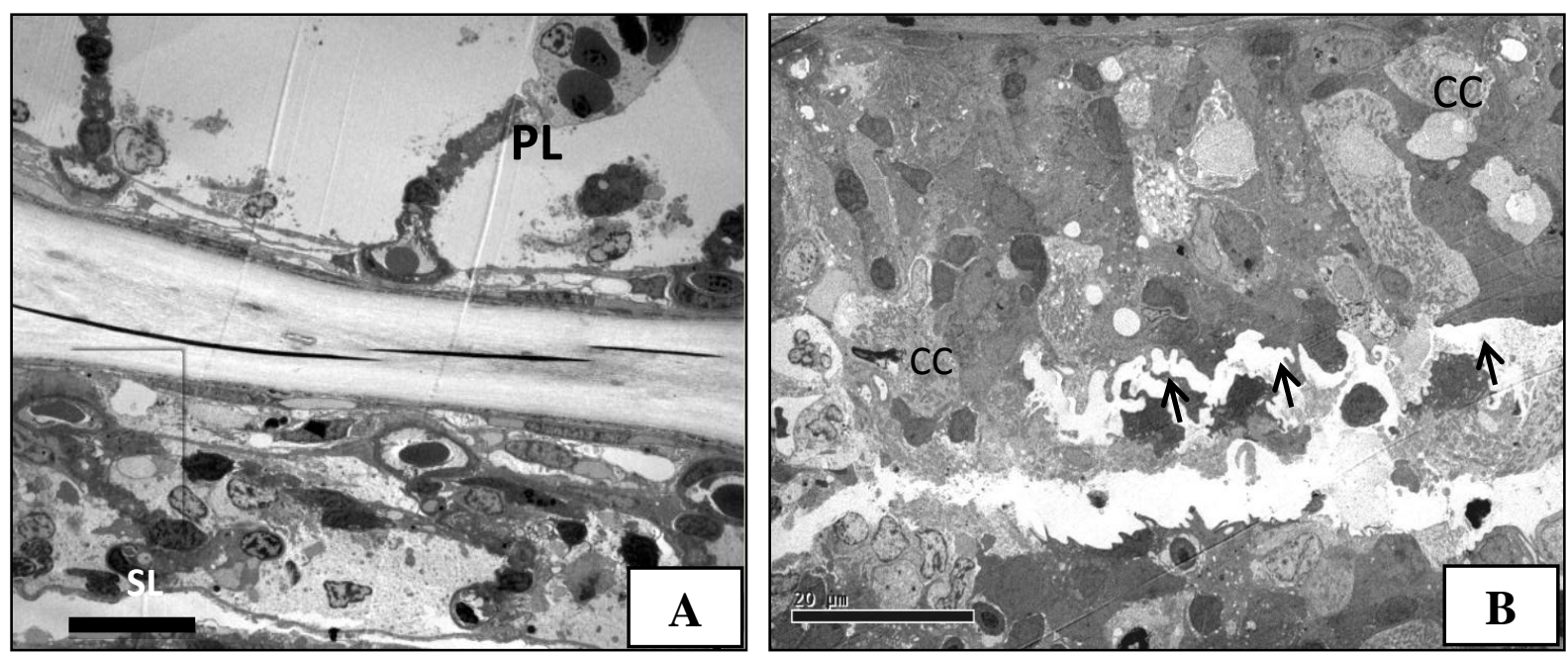

Figure 9. Electron micrographs of the gill of fish treated with $200 \mu \mathrm{g}$ AFB $1 / \mathrm{kg}$ for 30 days (A\&B); primary lamellae (PL); secondary lamellae (SL); chloride cell (CC); cell death (arrows).

\section{Aflatoxin B1 Residues}

Accumulation of AFB1 following dietary exposure in A. dispar liver and gills is summarized in Figure 10. No AFB1 was detected in the liver and gills of the control fish. In the fish treated with $50 \mu \mathrm{g} \mathrm{AFB} 1 / \mathrm{kg}$, AFB1 residues were not detected on days 10 and 20. However, AFB1 residues were detected on day 30 at this dosage. In fish treated with 100, 150 and $200 \mu \mathrm{g}$ AFB1/kg, AFB1 residues in liver and gill tissues increased as the exposure was prolonged and the concentration of AFB1 in the feed increased, with higher concentrations being detected on day 30 than on day 20.
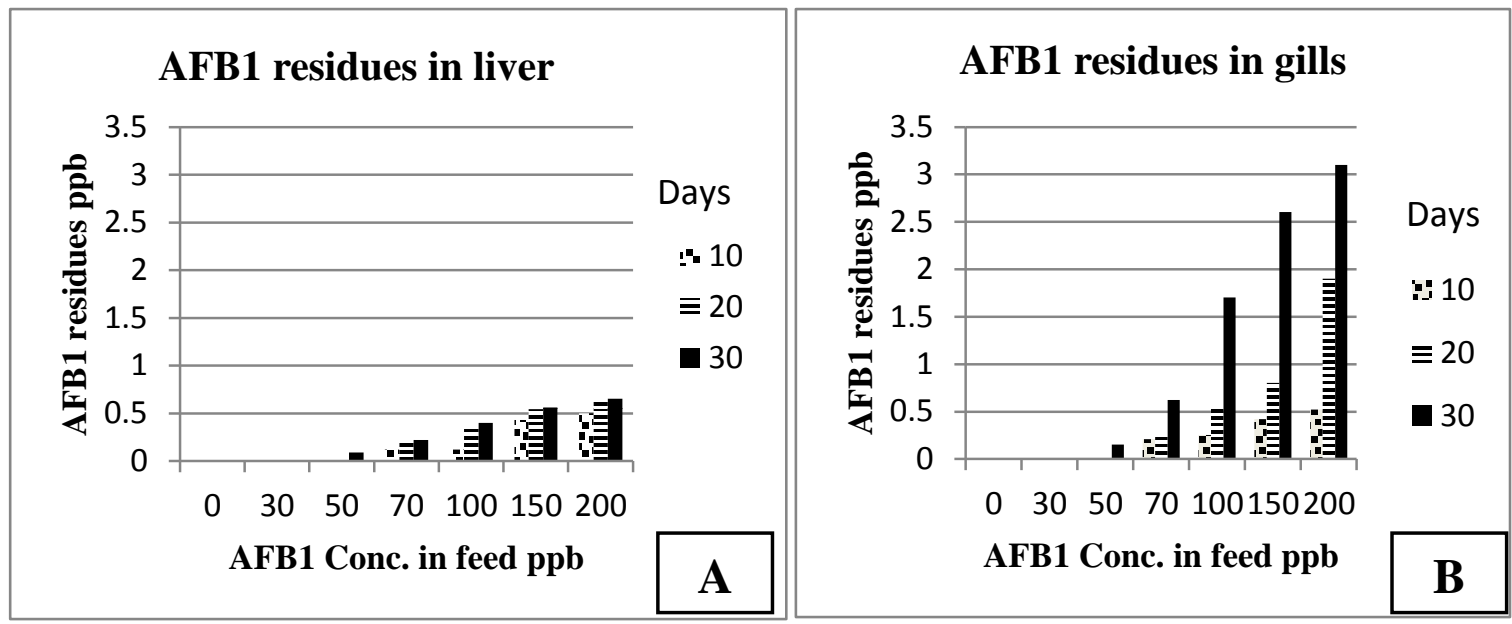

Figure 10. AFB1 residues in A. dispar in day 10, 20 and 30 of the exposure; A) AFB1 residues in liver tissues; B) AFB1 residues in gill tissues. $($ Control $=0 \mathrm{ppb})$.

\section{Discussion}

Exposure to aflatoxin is often associated with acute mortality in fish. Cagauan et al. [15] reported that tilapia (Oreochromis mossambicus) exposed to dosages of 53.02 - 115.34 AFB $1 \mu \mathrm{g} / \mathrm{kg}$ of feed had $67 \%$ mortality in 90 days. Anh et al. [9] found that tilapia fed with 10,000 AFB1 $\mu \mathrm{g} / \mathrm{kg}$ for 8 weeks had increased mortality. This notwithstanding, in the present study no mortality was reported, even though we used concentrations similar to Cagauan et al. [15]. However, presumably mortality could occur, if the exposure time lasted for a longer period.

The liver is the primary site of aflatoxin bioactivation and is normally the main site of toxicity [8]. We found no effect of aflatoxin after 30 days on liver histopathology at $50 \mu \mathrm{g}$ AFB $1 / \mathrm{kg}$. Anh et al. [9] showed no effect on Nile tilapia (Oreochromis niloticus) at concentrations up to $250 \mu \mathrm{g} / \mathrm{kg}$, and [16] showed no effect on black tiger shrimp (Penaeus monodon) fed with aflatoxin dosages up to $100 \mu \mathrm{g} / \mathrm{kg}$. There is some evidence that damage will 
occur following long-term chronic exposure, as [17] found liver tumors in rainbow trout fed with $0.5 \mu \mathrm{g}$ AFB1/kg for 6 months.

Stored glycogen was the most prominent feature in the hepatocytes of control fish. The concentration of glycogen decreased with both increasing time and increasing concentration dosages. Decreasing glycogen storage was also reported by [18] for Labeo calbasu and also [19] for rainbow trout (Oncorhynchus mykiss). Fatmi and Ruby [18] proposed that aflatoxin increased the energy demands on the fish, thus requiring the utilization of stored glycogen. The reduction of hepatic glycogen stores may also arise from either an inhibition of glycogenic enzymes, an inhibition of glyconeogenesis, a decrease in glucose transport into hepatocytes, or an increase in the activity of enzymes metabolizing glycogen precursors $[20,21]$. In the present study, the number and size of lipid droplets in the hepatocytes of treated fish liver increased as AFB1 concentration increased. Hussein and Brasel, [22] indicated that the increase in lipids is due to the reduction of enzyme synthesis and activity. Chou and Marth [23] suggested that the increase observed in the hepatic lipid production might be due to reduced oxidation of fats or increased lipid synthesis. Moreover, the present study showed damage to mitochondria which was also observed by [24]. Damage to mitochondria and the disappearance of cristae may result in decreased oxidation, which can cause accumulation of lipids in the liver [25]. Breakage of cell membranes, which would affect the normal cell functions and structure, was also seen in the present study. Rough endoplasmic reticulum (RER) showed some damage and loss of its arrangement in some areas. Sahoo et al. [26] reported that AFB1 disrupts RER, reduces RNA synthesis, the attachment of polyribosomes to RER, and damages ribosomes, thus severely affecting protein synthesis. Nuclear damage, including nuclear shrinkage, irregularity and condensation, was obvious. AFB1 interacts with the complex structure of chromatins, by forming DNA-AFB1 adducts [2]. These changes may damage the normal functioning of the nuclei, and affect DNA and RNA metabolism.

The gills are among the most vulnerable structures of the teleost fish because of their external location and intimate contact with water. They are liable to damage by any irritant materials whether dissolved or suspended in the water [27]. They are directly exposed to toxins occurring in the external environment which often cause pathological changes in fish [28]. At aflatoxin concentrations $\geq 100 \mu \mathrm{g}$, we observed hyperplasia of the epithelial layer of primary lamellae and fusion of secondary lamellae, desquamation of epithelial cells, and cellular degeneration which resulted in necrosis of the gill epithelial tissues by day 30 of the experiment. Changes in the present study were in agreement with the observation of [26] on Labeo rohita fish exposed to AFB1. Histopathological changes of the gills may result in hypoxia, respiratory failure, and problems with ionic and acidbase balance [29]. Ferguson [30] reported that the fusion and hyperplasia of gill lamellae may be induced by the effect of the toxin which alters glycoprotein in the mucus covering of the cells, thus affecting the negative charges of the epithelium and causing adhesion to the adjacent lamellae. Changes in the epithelial cells, such as hyperplasia and the fusion of some secondary lamellae, are examples of defense mechanisms which increase the distance between the external environment and the blood and thus serve as a barrier to the entrance of contaminants [31]. As a consequence of the increased distance between water and blood, the oxygen uptake is impaired [32]. Another finding in this study was chloride cell proliferation in the gills of fish treated with 100, 150 and $200 \mu \mathrm{g} \mathrm{AFB} 1 / \mathrm{kg}$. Pawert el al. [33] explained that the increased number of chloride cells may be due to increased secretion, or to adaptive processes to a different ionic environment. In the present study, the histopathological changes in the chloride cells may indicate osmoregulatory dysfunctioning.

Exposure to aflatoxin also increased mucus secretion by the gills, possibly leading to impaired gas exchange [33]. Microridges are known to have a mucus anchoring function that protects the epithelium against microbial or solid agents in suspension and are a mucus retention structure in gill epithelium [13]. They increase the surface area of the epithelial cells that are in contact with the external environment [34].

A number of studies have reported the detection of AFB1 residues in the liver and muscles of fish, but there is no information on the accumulation of aflatoxin in gills. Rajeev et al. [35] reported that AFB1 accumulation in the liver and muscle tissues of hybrid sturgeon fish increased with increasing dietary levels of the toxin in experimental diets. In the present study, the amount of AFB1 residues detected in liver tissues was lower than that detected in gills. One explanation is that the liver has the greatest concentrations of detoxifying enzymes, and that concentrations may therefore be lower in this organ. Randall et al. [36] demonstrated that the gills can be a major route of uptake even for chemicals with low water solubility.

\section{Conclusion}

AFB1 induced significant changes to the cellular organelles and architectures of major cell components. The histopathological changes and accumulation of AFB1 in A. dispar tissues were dose and time dependent. The structural changes of the cell organelles of the liver and gills due to dietary AFB1 exposure indicated a reduction in cell and tissue functionality, which could disrupt their metabolic and detoxification roles. The prolonged feeding of fish on low levels of dietary AFB1 $(50 \mu \mathrm{g}$ AFB1/kg) induced not only serious health problems in exposed fish that could result in economic losses for the fish industry, but also may represent a high risk to fish consumers through their residues in liver and gill tissues. 


\section{HISTOPATHOLOGICAL AND ULTRASTRUCTURAL CHANGES IN THE LIVER GILLS}

\section{References}

1. IARC. Some naturally occurring substances, food items and constituents, heterocyclic aromatic amines, and mycotoxins. IARC Monographs Evaluation of Carcinogenic Risks in Humans. International Agency for Research on Cancer World Health Organization, Lyon, France. 1993, 56, 489-521.

2. Santacroce, M.P., Conversano, M.C., Casalino, E., Lia, O., Zizzadoro, C. Centoducati, G. and Crescenzo, G. Aflatoxins in aquatic species: metabolism, toxicity and perspectives. Revs. in Fish Biol. and Fisheries, 2007, 18(1), 99-130.

3. Elshafie, A.E., Al-Lawatia, T., and Al-Bahry, S.N. Fungi associated with black tea and tea quality in the Sultanate of Oman. Mycopathologia, 1999, 145(2), 89-93.

4. Elshafie, A.E., Al-Rashdi, T.A., Al-Bahry, S.N and Bakheit, C.S. Fungi and aflatoxins associated with spices in the Sulatanate of Oman. Mycopathologia, 2002, 155, 155-160.

5. Elshafie, A.E, Al Siyabi, F.M., Salih, F.M., Ba Omar, T., Al Bahry, S.N. and Al Kindi, S. The Mycobiota of herbal drug plants in Oman and possible decontamination by Gamma radiation. Phytopathologia Mediterranea, 2003, 42(2), 149-154.

6. Williams, D.E., Orner, G., Willard, K.D., Tilton, S., Hendricks., J.D., Pereira, C., Benninghoff, A.D. and Bailey, G.S. Rainbow Trout (Oncorhynchus mykiss) and ultra-low dose cancer studies. Comparative Biochem. Physiol. Part C: Toxicol. \& Pharmacol., 2009, 149(2), 175-181.

7. El-Sayed, Y.S and Khalil, R.H. Toxicity, niochemical effects and residue of Aflatoxin B1 in marine waterreared Sea Bass (Dicentrarchus labrax L.). Food and Chemical Toxicol., 2009, 47(7), 1606-1609.

8. Hendricks, J.D. Carcinogenicity of aflatoxins in non- mammalian organisms. In: Eaton, D.L., Groopman, J.D. (Eds). The toxicology of aflatoxins: human health, veterinary, and agricultural significance. Academic Press, New York, 1994, pp 103-136.

9. Anh, T., Grizzle, J., Lovell, R., Manning, B, and Rottinghaus, G. Growth and hepatic lesions of Nile tilapia (Oreochromis niloticus) fed diets containing aflatoxin. Aquaculture, 2002, 212(1), 311-319.

10. Manning, B.B., Menghe, H.L. and Robinson, E.H. Aflatoxins from moldy corn cause no reductions in channel catfish Ictalurus punctutus performance. J. World Aquaculture Soc., 2005, 36(1), 59-67.

11. Mishra, H.N., Das, C. A review on biological control and metabolism of aflatoxin. Critical Reviews in Food and Nutrition, 2003, 43(3), 245-264.

12. Ba-Omar, T., Al-Jardani, S and Victor, R. Effects of Pesticide Temephos on the Gills of Aphanius dispar (Pisces: Cyprinodontidae). Tissue and Cell, 2011, 43, 29-38.

13. Al-Ghanbousi, R., Ba-Omar, T. and Victor, R. Effect of Deltamethrin on the gills of Aphanius dispar- A microscopic study. Tissue and Cell, 2012, 44(1), 7-14.

14. Macé, K., Aguilar, F., Wang, J.S., Vautravers, P., Gómez-Lechón, M., Gonzalez, F.J., Groopman, J., Harris, C.C. and Pfeifer, A.M.. Aflatoxin B1-induced DNA adduct formation and p53 mutations in CYP450expressing human liver cell lines. Carcinogenesis. 1997, 18(7), 1291-1297.

15. Cagauan, A.G., Tayaban, R.H., Somga, J.R., Bartolome, R.M. Effect of aflatoxin contaminated feeds in Nile tilapia (Oreochromis niloticus L.). In: Remedios, R.B., Mair, G.C., Fitzsimmons, K. Proceedings of the Sixth International Symposium on Tilapia in Aquaculture, 2004, pp. 172-178.

16. Boonyaratpalin, M., Supamattaya, K., Verakunpiriya, V. and Suprasert, D. Effects of aflatoxin B1 on growth performance, blood components, immune function and histopathological changes in black tiger shrimp (Penaeus monodon Fabricius). Aquaculture Res., 2001, (32), 388-398.

17. Halver, J.E. Aflatoxicosis and trout hepatoma. In: (L.A. Goldblatt ed.), Aflatoxin: scientific background, control and implications. Academic Press, New York, USA, 1969.

18. Fatmi, A and Ruby, D. Effect of aflatoxin on total serum protein and liver glycogen of Labeo calbasu, 2011, 6(4), 635-637.

19. Nunez, J.D. Hendriks and Duimishra, J.R. Ultrastructure of hepato-cellular neoplasm in aflatoxin B1 (AFB1)initiated rainbow trout (Oncorhynchus mykiss). Toxicological Pathology, 1991, 19(1), 11-21.

20. Kiessling, K.H. Biochemical mechanisms of action of mycotoxins. Pure Appl. Chem. 1986, 58, 327-338.

21. Hsieh, D.P.H. Mode of action of mycotoxins. In: Mycotoxins in food, 1987, pp. 149-176. http://thebioscan.in/Journals_PDF/6426-\%20AMJAD\%20FATMI.pdf

22. Hussein, H.S. and Brasel, J.M. Toxicity, metabolism, and impact of mycotoxins on humans and animals. Toxicology, 2001, 167(2), 101-134.

23. Chou. C.C. and Marth. E.H. Incorporation of $[2-14 C]$ acetate into lipids of mink (Mustela risen) liver and intestine during in vitro and in vivo treatment with aflatoxin B1. Appl. and Environmental Microbiology, 1975, 30: 946-950.

24. Radhika, G., Rajain, P.R., Kizhakkayil, C.G. and Nandiath, K.S. Ultrastructural changes in hepatopancreas of Penaeus mondon Fabricius given aflatoxin B1 diet. Aquaculture Res., 2012, 43, 32-43.

25. Terao, K. and Ueno, Y. Morphological and functional damage to cells and tissues. In: Toxicology, Biochemistry and Pathology of Mycotoxins, 1978, pp. 189-238.

26. Sahoo, P.K., Mukherjee, S.C., Jain, A.K., and Mukherjee, A. Histopathological and electron microscopic studies of gills and opisthonephros of Rohu, Labeo rohita to Acute and Subchronic Aflatoxin B1 toxicity. 
Asian Fisheries Science, 2003, 16(3/4), 257-268.

27. Roberts, J.R. The pathophysiology and systematic pathology of teleosts. In fish pathology. 1st Ed. 1978, pp. 67-70. Bailliere Tindall, London.

28. Mallatt, J. Fish gill structural changes induced by toxicants and other irritants; a statistical review. Canadian J. Fisheries and Aquatic Sciences, 1985, 42, 630-648.

29. Alazemi, B.M., Lewis, J.W. and Andrews, E.B. Gill damage in the freshwater fish, Gnathonemus ptersii (Family: Mormyridae) exposed to selected pollutants: an ultrastructural study. Environmental Technology, 1996, 17(3), 225-238.

30. Ferguson, H.W. Gills and pseudobranchs. In: Ferguson, H.W., (Ed.), Text book of systemic pathology of fish, 1 st ed., Lowa state University press, 1989, pp. 18-20. Amer, Lowa 500/0. Canada.

31. Hadi, A., Shokr, A. and Alwan, S. Effects of aluminum on the biochemical parameters of fresh waterfish tilapia zillii. J. Appl. Sciences, 2009, 3(1), 33-41.

32. Figueiredo-Fernandes, A., Ferreira-Cardoso, J.V., Garcia-Santos, S., Monteiro, S.M., Carrola, J., Matos, P., and Fontaínhas-Fernandes, A. Histopathological changes in liver and gill epithelium of Nile tilapia, Oreochromis niloticus exposed to waterborne copper. Brazilian J. Vet. Res., 2007, 27(3), 103-109.

33. Pawert, M., Mishra, S.K., Chattopadhyay, M., Patro, I.K. Neurotoxic logical effects of deltamethrin on the development of cerebellum of rat. J. Bioscience, 1998, 22(2), 117-130.

34. Machado, M.R. and Fanta, E. Effect of the organ phosphorous methyl parathion on the branchial epithelium of freshwater fish Metynnis roosevelti. Brazilian Archives of Biology and Technology, 2003, 46(3), 361-372.

35. Rajeev, R.P., Zhu, X., Lei, W., Han, D., Yang, Y., and Xie, S. Low Levels of Aflatoxin B1 could cause mortalities in juvenile hybrid sturgeon, Acipenser ruthenus male A. Baeri female. Aquaculture Nutrition, 2011, 17(2), 39-47.

36. Randall, D.J., Connell, D.W., Yang, R. and Wu, S.S. Concentrations of persistent lipophilic compounds in fish are determined by exchange across the gills, not through the food chain. Chemosphere, 1998, 37, 12631270 .

Received $1^{\text {st }}$ December 2014

Accepted 26 February 2015 